\title{
Stage IIIC2 Uterine Corpus Cancer AJCC v7
}

National Cancer Institute

\section{Source}

National Cancer Institute. Stage IIIC2 Uterine Corpus Cancer A/CC v7. NCI Thesaurus.

Code C95176.

Stage IIIC2 includes: T1-T3, N2, M0. T1: Tumor confined to corpus uteri. T2: Tumor invades stromal connective tissue of the cervix but does not extend beyond uterus. T3:

Tumor involves serosa and/or adnexa, vagina, or parametrial tissue. N2: Regional lymph node metastasis to para-aortic lymph nodes, with or without positive pelvic lymph nodes. M0: No distant metastasis. This staging applies to carcinomas and carcinosarcomas. (AJCC 7th ed.) 